\title{
Comprehensive Assignments of Extraction, Isolation and Characterization of Taraxerol from Bark Annona reticulata L. and Chemopreventive Effect on Human Prostate Cancer Cell Lines (lncap and pc-3)
}

\section{Saritha Surapaneni and Prakash T* \\ Department of Pharmacology, Acharya and BM Reddy College of Pharmacy, Bangalore, India}

"Corresponding author: Dr. T. Prakash, Department of Pharmacology, Acharya and BM Reddy College of Pharmacy, Bangalore-560 107, Karnataka, India, Tel: +918892943090; E-mail: prakasht@acharya.ac.in

Received date: March 03, 2018; Accepted date: March 21, 2018; Published date: March 28, 2018

Copyright: ( 92018 Surapaneni S, et al. This is an open-access article distributed under the terms of the Creative Commons Attribution License, which permits unrestricted use, distribution, and reproduction in any medium, provided the original author and source are credited.

\begin{abstract}
Prostate Cancer (PC) ruins a foremost cause of death of males in the US as well its growth rate is increased in the rest of the world. The current learning aims to perform a preliminary photochemical analysis by the successive extraction of the bark of Annona reticulata L. using petroleum ether, chloroform, and ethanol. The isolation, structure elucidation and identification of Taraxerol and check up in vitro study in prostate carcinoma. The structure was elucidated by spectroscopic techniques included Thin Layer Chromatography (TLC) and High Performance Liquid Chromatography (HPLC), UV and Gas Chromatography-Mass Spectrometric (GC-MS). The prostate cell lines, LNCaP and PC-3 cell lines was cultured and antiproliferative effect by MTT Method, Neutral red cytotoxicity, measurement of LDH release, determinations of apoptosis by Acridine Orange (AO) and Ethidium Bromide (EB) double staining. Inhibition of protein denaturation, caspase levels by indirect ELISA and DNA fragmentation was performed. Investigation of the phytochemical summary on the bark of $A$. reticulata $L$. reports the occurrence of flavonoids, saponins, triterpenoid and tannins. In-vitro experiments show the selected compound exhibited of cytotoxicity against the cancer cell lines. An increase in caspase activity or caspase levels is generally considered as indicators of cellular apoptosis. The compounds to prevent heat associated denaturation of albumin are measured as a screening method for assessing anti-inflammatory potential of compounds.
\end{abstract}

Keywords: $A$. reticulata $L$; Triterpinoid; Taraxerol; Gas chromatography-mass spectrometric (GC-MS); MTT assay; DNA fragmentation; Caspase- $3 / 7$

\section{Abbreviation:}

ANOVA: Analysis of Variance; DHT: Dihydrotestosterone; TLC: Thin Layer Chromatography; HPLC: High Performance Liquid Chromatography; GC-MS: Gas Chromatography-Mass Spectrometric; AO: Acridine Orange; EB: Ethidium Bromide

\section{Introduction}

Phytochemical and pharmacological activities of components imply a broad range of clinical application in lieu of cancer therapy. Some of these plants exhibited a wide range of biological activities such as cytotoxicity [1]. The current investigation deals with the qualitative and quantitative pharmacognostical assessment of the bark of $A$. reticulata $L$. investigation reports the isolation of a triterpenoid glycoside from the bark of $A$. reticulata $L$. The compound gave positive colour reactions with specific spray reagents indicating that it may be a triterpenoid. It gave a pink spot on spraying with LiebermannBurchard reagent with Vanillin-sulphuric acid reagent the compound gave a violet colour. A. reticulata L. (Family: Annonaceae) small deciduous green tree commonly called as bullock's heart widely distributed in tropical and subtropical regions [2]. In vivo cycling of cancer cells has been established to be a useful method to select for extremely aggressive cell lines. The human prostate cancer cell lines, PC-3 and LNCaP, were beforehand cycled in vivo to choose for tremendously metastatic variant from sentinel lymph node metastasis.
These human cancer models contain proven highly advantageous to the prostate cancer research community [3]. Human prostate cancer cell lines are one of the cell lines used in prostate cancer research. These cells are useful in investigating the biochemical changes in advanced prostatic cancer cells and in assessing their response to chemotherapeutic agents. Moreover, they can be used to create subcutaneous tumors in mice in order to investigate a model of the tumor environment in the context of the organism [4]. Taraxerol, a triterpenoid compound, has potent anti-inflammatory effects according to review of literature statistics suggest that Taraxerol down regulates the turn of phrase of proinflammatory mediators in macrophages by interfering with the activation of TAK1 and Akt, thus prevent NF- $\kappa \mathrm{B}$ activation [5].

\section{Materials and Methods}

\section{Collection and authentication of the plant material}

The fresh bark of Annona reticulata $L$. were collected washed and dried from the plant in the month of July 2014 and authenticated by Dr. Ajmeera Ragan and the voucher specimen was preserved within the herbarium of the university.

\section{Preparation of successive extracts}

The mature bark of collected locally were cleaned with water, shade dried and grounded into fine powder $200 \mathrm{~g}$ of $A$. reticulata L. the dried bark powder using Soxhlet apparatus. Each extract obtained following successive extraction was filtered using Whatman No. 1 filter paper, dried to a semisolid mass using water bath and the yield of each extract 
thus obtained was recorded and stored in a refrigerator at $40^{\circ} \mathrm{C}$ till further use [6].

\section{Photochemical analysis}

A stock focus on $1 \%(\mathrm{~W} / \mathrm{V})$ of every successive extract obtain using petroleum ether, chloroform; ethanol was geared up using the respective solvent. These extract beside with positive controls were tested for the existence of active phytochemicals of tannins, alkaloids, phytosterols, triterpenoid, flavonoids, cardiac glycosides, anthraquinone glycosides, saponins, carbohydrates, proteins, amino acids and fixed oils and fats following standard methods $[7,8]$. The crude extract was suspended in water and n-hexane successively to afford n-hexane water soluble, respectively. Purification of n-hexane soluble fraction by column chromatography.

\section{Isolation of taraxerol}

Preparation of Column-Thin-layer chromatography was adopted by the Suvarchala. Liquid Chromatography Profiling of Taraxerol in crude extract materials used and Taraxerol HPLC grade methanol, Sonicator, Thermo fisher's instruments with PDA detector $(200 \mathrm{~nm}-600 \mathrm{~nm})$, Syncronis C18 $(250 \times 4.6) \mathrm{mm}$ with particle size of $5 \mu$. Mobile phase(1) Buffer: Methanol in the rate of 0.5: 9:5 at the flow rate of 1.2 $\mathrm{ml} / \mathrm{min}$ (2) Method: Isocratic (3) Injection volume $10 \mu \mathrm{l}$. Sample Preparation-10 mg of sample is dried and crushed and dissolve in 10 $\mathrm{ml}$ of HPLC grade methanol.

Standard Preparation: Taraxerol used as standard and was preparation run under similar condition. The wave length for maximum absorption of Taraxerol is $211 \mathrm{~nm}$ and the flow rate was maintained at $1-2 \mathrm{ml} / \mathrm{min}$. Sample and standards solution as well as the mobile phase were degassed and filtered through $0.45 \mu \mathrm{m}$ membrane filter (Millipore). A chromatographic operation was carried out at ambient temperature.

Method: Separation was done in the isocratic mode using potassium di hydrogen Orthophosphate buffer KH2B4: Methanol (0.5: 9.5\%) at a flow rate of $1.2 \mathrm{ml} / \mathrm{min}$ with an injection volume of $10 \mu \mathrm{l}$ : UV detection was at $211 \mathrm{~nm}$. Identification of the compound was done by comparison of that retention's time and UV absorption spectrum with those of standards.

\section{Solubility: Methanol [9].}

General experimental procedure: The HPLC UV spectrum was recorded on a thermo fisher. The FT-IR spectra obtained, on a Bruker Tensor 27 FT-IR type spectrometer, $1 \mathrm{H}$ and 13C NMR were recorded on Bruker $400 \mathrm{MHz}(1 \mathrm{H}: 400 \mathrm{MHz}, 13 \mathrm{C}: 400 \mathrm{MHz})$ Spectroscopy analytical test facility, Society for innovation and development (SID), NMR data centre, Indian institute of Science Bangalore.

In vitro Cell culture PC3 (human prostatic carcinoma) LNCaP ( human prostate adenocarcinoma cells) cell line was initially procured from National Centre for Cell Sciences (NCCS), Pune, India and maintained Dulbecco's modified Eagles medium (Gibco, Invitrogen). The cell line was cultured in $25 \mathrm{~cm}^{2}$ tissue culture flask with (Dulbecco's modified Eagles medium) DMEM supplemented with 10\% (Fetal bovine serum) FBS, L-glutamine, sodium bicarbonate and antibiotic solution containing: Penicillin $(100 \mathrm{U} / \mathrm{ml})$, Streptomycin $(100 \mu \mathrm{g} / \mathrm{ml})$, and Amphotericin B $(2.5 \mu \mathrm{g} / \mathrm{ml})$. Cultured cell lines were kept at $37^{\circ} \mathrm{C}$ in a humidified $5 \% \mathrm{CO}_{2}$ incubator (Thermo Fisher Scientific, Bangalore). The viability of cells were evaluated by direct observation of cells by Inverted phase contrast microscope and followed by MTT assay method. Antiproliferative effect by MTT Method For the MTT assay Fifteen mg of MTT (Sigma, M-5655) of reagent was used as previously described in Deep et al. The absorbance values were measured by using micro plate reader at a wavelength of $570 \mathrm{~nm}$ and discussed $[10,11]$. The percentage of growth inhibition was intended using the formula: \% of viability=Mean OD Samples $\times$ 100 Mean OD of control group. Neutral Red Assay was performed according to the method adopted from Zhang. The absorbance was measured using micro plate's reader at $540 \mathrm{~nm}$ and the percentage viability was calculated [12]. LDH (Lactate Dehydrogenase Assay) release assay was performed with cell free supernatant collected from culture plates exposed to different concentration of silver nanoparticles $(5,14,28,56,200 \mu \mathrm{g} / \mathrm{ml})$ and the method adopted from Laurenzana et al. [13].

\section{Determinations of apoptosis by acridine orange (AO) and ethidium bromide (EB) double staining}

DNA-binding dyes AO and EB (Sigma, USA) are used for the morphological detection of apoptotic and necrotic cells. AO is taken up by both viable and non-viable cells and emits green fluorescence if intercalated into double stranded nucleic acid (DNA). EB is taken up only by non-viable cells and emits red fluorescence by intercalation into DNA. The cells were cultured in Dulbecco's modified Eagles media and grown to $60-70 \%$ confluency and treated at final concentrations. The cells were washed by cold PBS and then stained with a mixture of $\mathrm{AO}(100 \mu \mathrm{g} / \mathrm{ml})$ and $\mathrm{EB}(100 \mu \mathrm{g} / \mathrm{ml})$ at room temperature for $10 \mathrm{~min}$. The stained cells were washed twice with 1X PBS and observed by a fluorescence microscope in blue filter of fluorescent microscope (Olympus CKX41 with Optika Pro-5 cameras). The cells were divided into four categories as follows: living cells (normal green nucleus), early apoptotic (bright green nucleus with condensed or fragmented chromatin), late apoptotic (orange-stained nuclei with chromatin condensation or fragmentation) and necrotic cells (uniformly orangestained cell nuclei) [14].

\section{Caspase levels by indirect ELISA}

Cell lysate (100 $\mu \mathrm{l}$ each) was added to the 96 well plate/and kept in incubation for $37^{\circ} \mathrm{C}$ overnight. The following day, the wells were drained and washed with PBS for 3 to 5 times Added $200 \mu \mathrm{l}$ of blocking buffer ( $1 \mathrm{~h}$ at room temperature) Composition- $0.2 \%$ gelatin in $0.05 \%$ tween 20 in PBS (freshly prepared) and washed with PBS TWEEN (2 times). Add $100 \mu \mathrm{l}$ of primary antibody (Anti human, caspase 9 Santhacruz, USA) and kept for 2 hours at room temperature. The antibody was washed in PBS (2 times). Added secondary antibody (antihuman HRP conjugated secondary antibody-100 $\mu$ l) and left for 1 $h$ at room temp. Washed with PBS TWEEN for two times and added with $200 \mu$ of chromogen for $30 \mathrm{~min}$ at room temperature in dark conditions. The colour was developed using $\mathrm{O}$ dianizdine hydrochloride and the reaction was stopped by adding 5N HCL $(50 \mu \mathrm{l})$ OD was read at $415 \mathrm{~nm}$ in an ELISA reader and relative absorption.

O-dianizdine (composition-1 $\mathrm{mg} / 100 \mathrm{ml}$ methanol $+21 \mathrm{ml}$ citrate buffer $\mathrm{pH}-5+60 \mathrm{ml} \mathrm{H} \mathrm{O}_{2}$ Percentage increase of caspase activity $=(\mathrm{OD}$ of test-OD of control)/OD of test X 100.

Caspase-9 (also known as Mch6, Apaf-3 or IC E-LAP-6) is a member of the Interleukin-1 $\beta$ Converting Enzyme (ICE) family of cysteine proteases. Caspase- 9 exists in cells as an inactive $46 \mathrm{kDa}$ proenzyme, called pro-Caspase-9. Pro-Caspase- 9 is cleaved to active 35 and $10 \mathrm{kDa}$ subunits by complexing with a cofactor, Apaf-1, 
through a caspase recruitment domain (CARD) and with cytochrome c during apoptosis. The downstream substrates of Caspase-9 include Caspases-3 and -7. Caspase-9 plays a critical role in the survival of neuronal progenitors within the embryonic forebrain and cortex. Phosphorylation of Caspase-9 by Akt, a serine/threonine kinase, inhibits its protease activity. The Caspase- 9 colorimetric protease assay provides a simple and convenient means for quantitating the enzyme activity of caspases that recognize the amino acid sequence, LEH. The cells were treated with $97.2 \mu \mathrm{g} / \mathrm{ml}$ of sample and incubated for $24 \mathrm{~h}$. The cells were digested after incubation with cell lysis buffer and the supernatant was coated on to a 96 well plate. $100 \mu$ l of primary antibody (Invitrogen, USA) was added to each well and incubated for 2 $\mathrm{h}$ at room temperature. After PBS washing nonspecific binding was avoided by using 3\% BSA in PBS. The wells were washed with PBS and added with $100 \mu \mathrm{l}(1: 1000) \mathrm{HRP}$ conjugated secondary antibody (Santa Cruz, USA). Color was developed using Danisidine- $\mathrm{H}_{2} \mathrm{O}_{2}$ substrate and read using an ELISA reader at $410 \mathrm{~nm}$ [15].

\section{DNA fragmentation}

The cell was implanted in 6 well plates. After attaining $60 \%$ confluency, in PC-3 and LNCaP cell lines was added, an untreated control cells site also maintained and incubated. The cell was totally centrifuged for $5 \mathrm{~min}$ at $3,000 \mathrm{rpm}$ in a micro centrifuge. The pellets thus obtain and washed twice through PBS (137 mM NaCl, $27 \mathrm{mM}$ $\mathrm{KCl}, 100 \mathrm{mM}$ NaHPO, $2 \mathrm{mM} \mathrm{KHPO}, \mathrm{pH}$ 7.4). Then the pellet was resuspended in $0.5 \mathrm{~mL}$ of lysis buffer $(10 \mathrm{mM}$ Tris- $\mathrm{HCl}, \mathrm{pH} 8.5,5 \mathrm{mM}$ EDTA, $200 \mathrm{mM} \mathrm{NaCl}, 0.2 \% \mathrm{SDS}$ ) and incubated at $60^{\circ} \mathrm{C}$ for $5 \mathrm{~min} .2 .5$ $\mu \mathrm{L}$ of Thermo Scientific Proteinase K (Cat \#EO0491, EO0492) and $5 \mu \mathrm{L}$ of Thermo Scientific RNase A/T1 Mix (Cat \#EN0551) were added to it. It was incubated at $60^{\circ} \mathrm{C}$ for $1 \mathrm{~h} .250 \mu \mathrm{L}$ of $5 \mathrm{M} \mathrm{NaCl}$ was added drop by drop and mixing was done properly follow by incubation on ice for $5 \mathrm{~min}$ to precipitate protein and centrifugation done for $15 \mathrm{~min}$ at $10,000 \mathrm{rpm}$ in a micro centrifuge and the supernatant transferred to a fresh tube then equal volume of isopropanol added to it and mixed well still the precipitate of the DNA is formed The cells were again centrifuged for $10 \mathrm{~min}$ at $10,000 \mathrm{rpm}$ in a micro centrifuge complete supernatant was discarded and the pellet was washed by means of 1.2 $\mathrm{mL} 70 \%$ cold ethanol the DNA pellet is dried and suspended in TE buffer.

Loading order: M-Marker, Lane 1-Control untreated PC-3 cells, Lane 2-Control untreated LNCaP cells Lane 3-PC-3 cells treated with compound, Lane 4: LnCap cells treated with compound [15].

\section{Results and Discussion}

The proportion of yield of petroleum (6.58), chloroform (8.20), and ethanolic (18.26) was recorded. Phytochemical investigation of petroleumether, chloroform, etanolic extract of $A$. reticulata $L$. were recorded and bark extract show the presence of phytochemical constituents namely, Pet ether extract gives: +ve test for Sterols, Fats and Fixed oils. Chloroform extract gives: +ve test for alkaloids, nonsugar moieties for glycosides, triterpenoid and tannins. Ethanolic extracts gives +ve test for flavanoids saponins, triterpenoid tannins. Sample was crystallized from n-hexane/acetone (15:1) as white needles, Melting Point: $303-305^{\circ} \mathrm{C}$. It gave pale of colors' (pink to blue to green) to Liebermann-Burchard test. Hence, the compound was identified. TLC analysis of the fractions using solvent systems nhexane/acetone (15:1), exposed the presence of shows potential spots as shown in TLC no. of spots- 1 , Rf values- 0.59 . While the IR spectrum exhibit peak at $3494.51(\mathrm{OH})$ stretching, $2941.11(\mathrm{C}-\mathrm{H})$ alkyl stretching, $1681.65(\mathrm{C}=\mathrm{C})$ cyclic bending $\mathrm{cm}-1$ and $1043.9(\mathrm{C}-\mathrm{H})$ cyclic stretching (Figure 1). Broadband at $3419.2 \mathrm{~cm} 1$ indicate its triterpenoid property [16]. Based upon the HPLC it can be finished that retention of sample and Taraxerol was initiate to be 3.13 and 3.11 respectively observed in (Figure 2) by compare the preservation factor and the reaction of the peak in the chromatogram of the standard by means of the illustration chromatogram, the classification of the isolated compound as Taraxerol based upon retention of the paradigm and sample $\lambda$ max of sample and standard was establish to be $211 \mathrm{~nm}$ based on UV spectroscopic studies explained in (Figure 3). The use of a mixture of chromatographic and spectroscopic techniques is necessary. With the application of various stationary phases, solvent systems and spray reagents, TLC proved to be a significant method for the characterization of sample mixtures [17]. HPLC was an effective and quicker instrument for the complete or at least partial quantitative separation of individual samples. For qualitative separation and quantitation GC is exceedingly capable whereas for identification and structure elucidation GC-MS and NMR are important methods. 21 Steroidal based nuclei is confirmed by (UV, IR and $1 \mathrm{H}$ NMR, 13C NMR, GCMS are explained [18]. Basic nuclei occurrence of functional groups like $\mathrm{OH}$ stretching, $\mathrm{C}-\mathrm{C}$ aryl bending, $\mathrm{C}-\mathrm{H}$ alkyl stretching, $\mathrm{C}$ $\mathrm{H}$ aryl stretching like $\mathrm{OH}$ and Cyclic rings being confirmed by IR stretching and bending vibrations. Nature of proton of $\mathrm{CH}_{3}, \mathrm{CH}_{2}, \mathrm{CH}$, $\mathrm{OH}$, types being identified HNMR1 spectroscopy explained in (Figures 3-5) [16]. The nature of tertiary, secondary, primary and methyl carbon the corresponding delta values in association with expected structures further the structure is confirmed by mass spectrum the $\mathrm{m} / \mathrm{e}$ value observed $(73,147,207,221,281,341,355,401,426)$ was in connection with parallel fragmentation patterned explained in (Figure 6) [17-19]. In order to assess the in-vitro analysis of Taraxerol in prostate cancer cells, the androgen-dependent LNCaP and androgen independent PC-3 cells (Figure 7) were treated with Taraxerol and the analysis of proportion of viable cells revealed that at a concentration of $100 \mu \mathrm{g} / \mathrm{ml}$ sample Taraxerol, there were nearly $49.8 \%$ viable cells. The IC 50 of the sample Taraxerol was estimated to be $97.26 \mu \mathrm{g} / \mathrm{ml}$ in PC-3 and LNCaP is estimated as $80.61 \mu \mathrm{g} / \mathrm{ml}$ on the cultured cells. MTT results (Figures 8-10) exhibits a substantial decrease in cell viability in a concentration dependent manner [20]. $100 \mu \mathrm{g}$ of compound reduced the cell viability to $47.87 \%$ with IC 50 value of $80.16 \mu \mathrm{g} / \mathrm{ml}$ suggest significant anticancer activity. This can be outstanding to the effect of sample Taraxerol, which induces apoptosis. And it can be conditional that the sample at a lower concentration might show good anti-cancer activity. The neutral red uptake assay delivers a quantitative estimation of the amount of viable cells in the treated cell lines. LDH is used as a quantitative enzyme for the intact cells; quantity of LDH leakage is an important test for cellular membrane permeabilization since it indicates several irreversible cell damage. LDH is an intracellular enzyme and leakage of $\mathrm{LDH}$ to media depicts loss of membrane integrity and in the current study treatment with Taraxerol has increased LDH leakage to media confirming apoptosis/necrosis can be interrelated with (Figure 11) [21]. Neutral red cytotoxicity test was based on the aptitude of living cell to uptake and bind neutral red is a positively stimulating dye that easily diffuses through cellular cytoplasm and stores in the acidic atmosphere of lysosomes. Principle of test is that neutral red is absorbed and bound only by live cell, while this ability is declined or damage in lifeless cells explained in (Figure 12) [22]. The amount of stored neutral red was thus right proportional to the sum of live cells in cell culture. In neutral red it can be seen that according to a dose-dependent manner the proportion of viable cells are getting decreased. Double staining method (AO/Et-Br staining) for evaluating the cytotoxic impact of Taraxerol revealed the statistic that 
the Taraxerol is capable of inducing apoptosis. The proportion of live cells decreased on increase in concentration. The reduction in live cells and increase in apoptotic cells indexed the toxic effect of Taraxerol exerted on the Taraxerol treated PC-3 cells. Apoptosis popularly take place within developmental circumstances in reaction to physiological stimuli such as hormones and is dependent on de novo gene expression. In malice of the perceived omnipresence of this observable fact, little is known about what tells a cell to die and less still about the physiological and molecular mechanisms that bring about death. Treatment with compound shows in LNCaP cells with red fluorescent nuclei an indicator of apoptosis in (Figure 13). Inhibition of protein denaturation of the sample is assessed the length of with the diclofenac sodium the capability of compounds to prevent heat associated denaturation of albumin is measured as a screening method for evaluation anti-inflammatory potential of compounds. Diclofenac sodium is measured as a potent standard and the ability of compound to resist protein denaturation is expressed in standardising of percentage inhibition shows effective in (Figure 14). DNA fragmentation is used to confirm initiation of apoptosis by compound treated. The results clearly depict increased fragmentation in both PC3 and LNCaP upon compound treatment which can be attributed to the apoptotic movement of compounds in (Figure 15). Caspases mainly considered as major indicators in apoptosis as pro caspases are initiated during apoptosis. An raise in caspase activity or caspase levels is generally considered as indicator of cellular apoptosis. In our study it can be observed that treatment of compounds increased the relative caspase 3 levels to $49 \%$ suggesting cellular apoptosis (Figure 16).

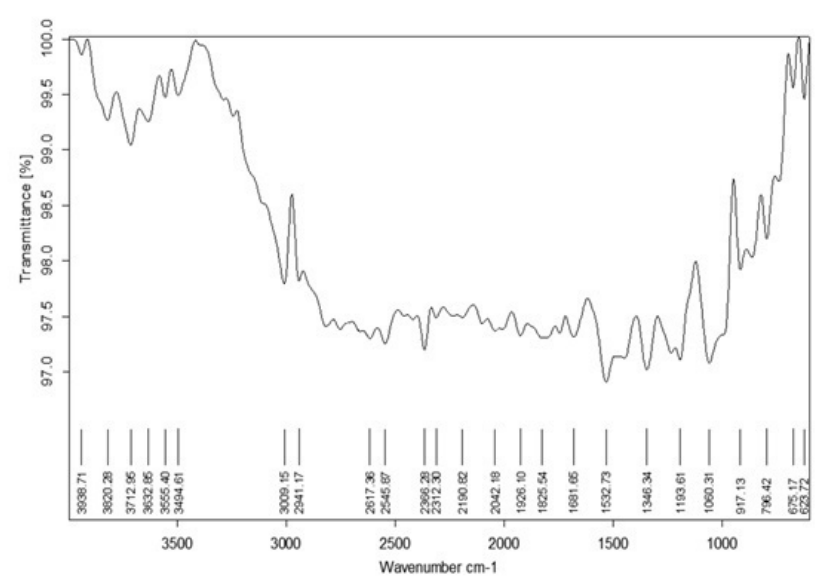

Fig. 1. Fourier transform infrared spectroscopy (FTIR) of Sample

Figure 1: Fourier transform infrared spectroscopy (FTR) of sample.

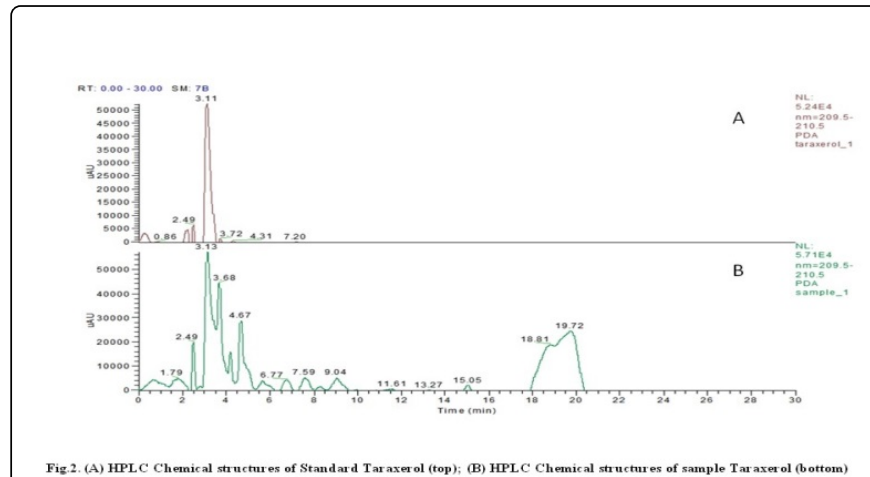

Figure 2: A) HPLC Chemical structures of standard Taraxerol (top). B) HPLC Chemical structures of sample Taraxerol (bottom).

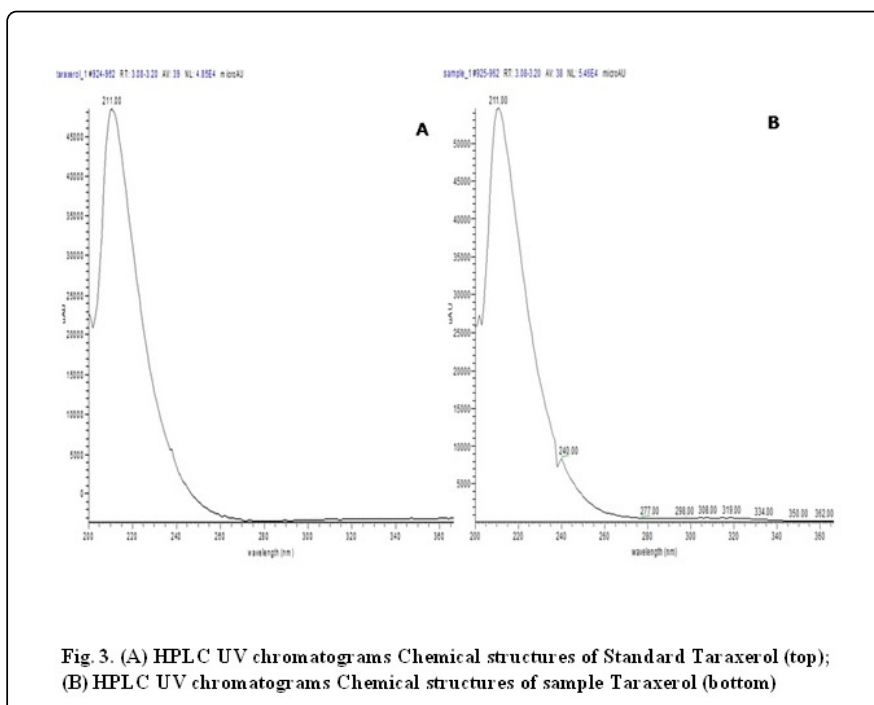

Figure 3: A) HPLC UV chromatograms Chemical structures of Standard Taraxerol (top). B) HPLC UV chromatograms Chemical structures of Sample Taraxerol.

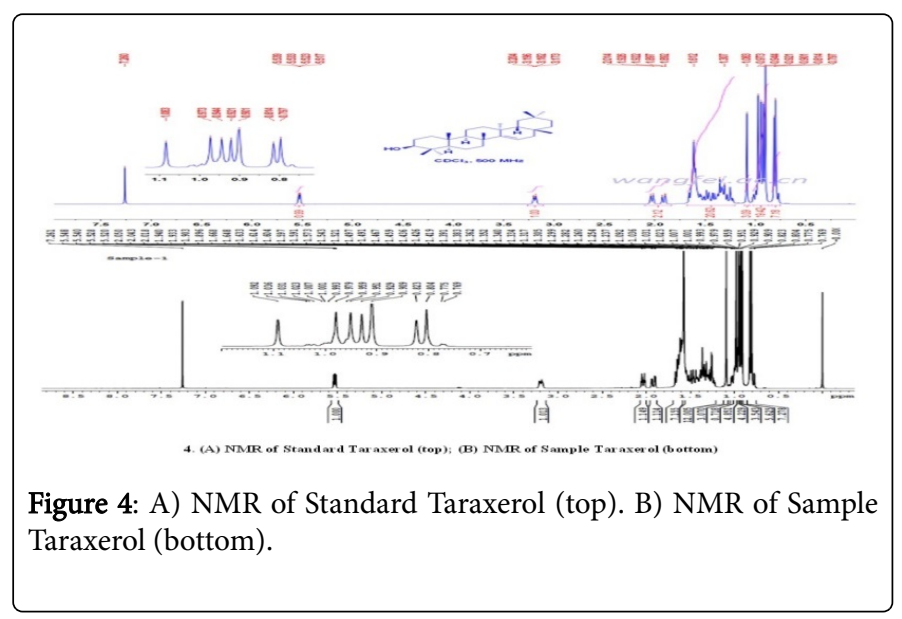


Citation: Saritha S, Prakash T (2018) Comprehensive Assignments of Extraction, Isolation and Characterization of Taraxerol from Bark Annona reticulata L. and Chemopreventive Effect on Human Prostate Cancer Cell Lines (Incap and pc-3). J Carcinog Mutagen 9: 313. doi:10.4172/2157-2518.1000313

Page 5 of 8

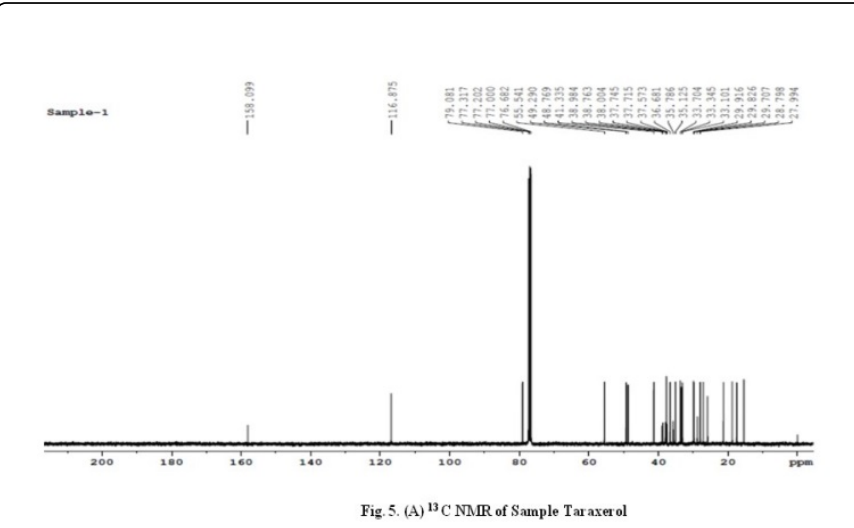

Figure 5: 13C NMR of Sample Taraxerol.

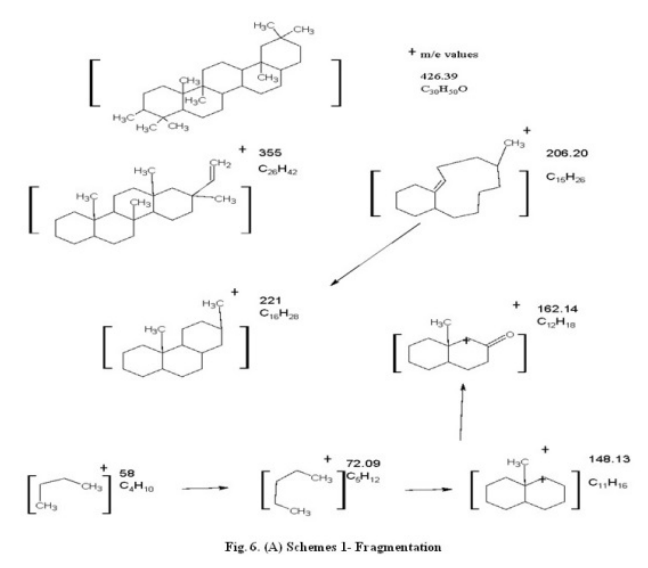

Figure 6: Schemes 1-Fragmentation.
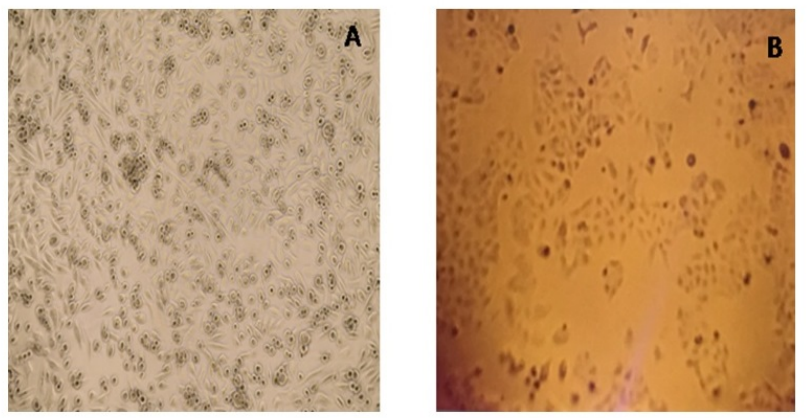

Fig. 7. (A) PC-3 Cells at confluency $80 \%$ picture (B) LNC aP Cells at confluency $80 \%$ picture

Figure 7: A) PC-3 Cells at confluency $80 \%$ picture. B) LNCaP Cells at confluency $80 \%$ picture.

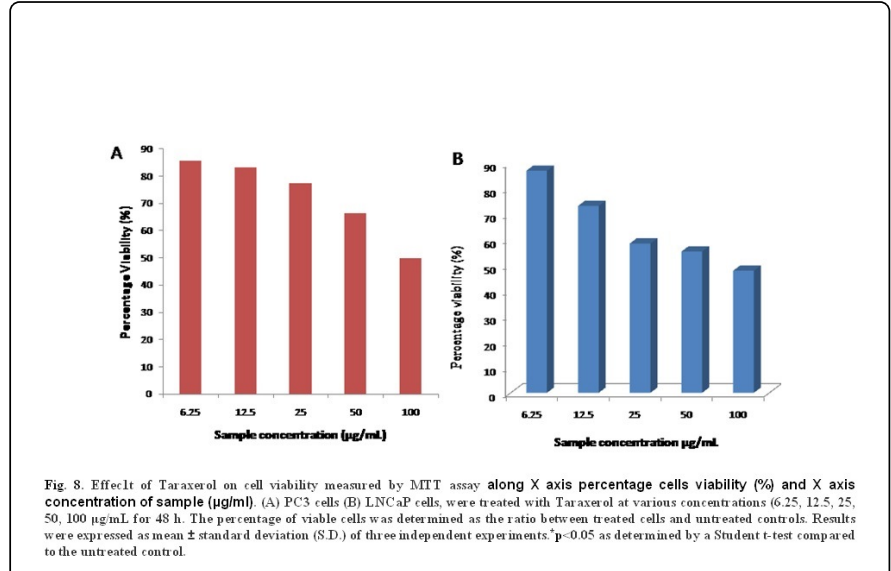

Figure 8: Effect of Taraxerol on cell viability measured by MTT assay along $\mathrm{X}$ axis percentage cells viability (\%) and $\mathrm{X}$ axis concentration of sample ( $\mu \mathrm{g} / \mathrm{ml})$. A) PC3 cells .B) LNCaP cells, were treated with taraxerol at various concentrations $(6.25,12.5,25,50$, $100 \mu \mathrm{g} / \mathrm{ml}$ for $48 \mathrm{~h}$. The percentage of viable cells was determined as the ratio between treated cells and untreated controls. Results were expressed as mean \pm standard deviation (SD) of three independent experiments ${ }^{*} \mathrm{p}<0.05$ as determined by a student $\mathrm{t}$-test compared to the untreated control.
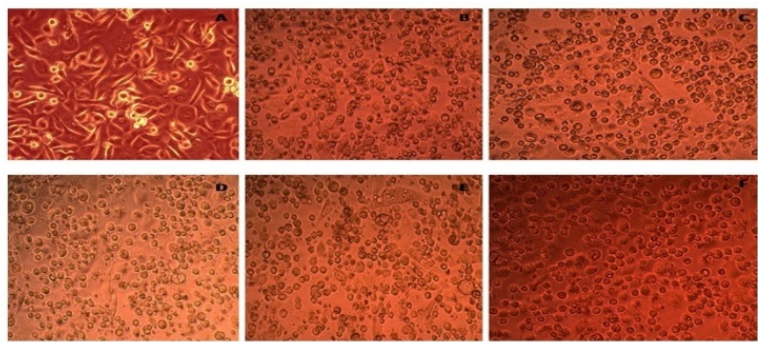

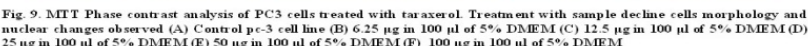

Figure 9: MTT phase contrast analysis of PC3 cells treated with taraxerol.treatment with simple decline cells morphology and nuclear changes observed. A) Control pc-3 cell line. B) $6.25 \mu \mathrm{g}$ in $100 \mu \mathrm{l}$ of $5 \%$ DMEM. C) $12.5 \mu \mathrm{g}$ in $100 \mu \mathrm{l}$ of 5\% DMEM. D) $25 \mu \mathrm{g}$ in $100 \mu \mathrm{l}$ of 5\% DMEM. E) $50 \mu \mathrm{g} \mathrm{IN} 100 \mathrm{Ml}$ of 5\% DMEM. F) 100 $\mu \mathrm{g}$ in $100 \mu \mathrm{l}$ of $5 \%$ DMEM. 
Citation: Saritha S, Prakash T (2018) Comprehensive Assignments of Extraction, Isolation and Characterization of Taraxerol from Bark Annona reticulata L. and Chemopreventive Effect on Human Prostate Cancer Cell Lines (Incap and pc-3). J Carcinog Mutagen 9: 313. doi:10.4172/2157-2518.1000313
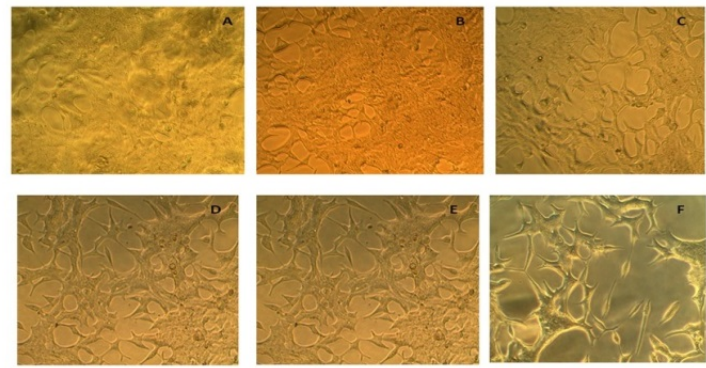

Fig. 10. MrT Phase contrast analysis of LNC aP cells treated with tar axerol. Treatnent with sample decline cells morphology and nuclean

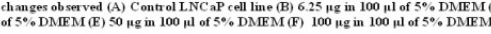

Figure 10: MTT phase contrast analysis of LNCaP cells treated with taraxerol. Treatment with sample decline cells morphology and nuclear changes observed. A) Control LNCaP cell line. B) $6.25 \mu \mathrm{g}$ in $100 \mu \mathrm{l}$ of $5 \%$ DMEM. C) $12.5 \mu \mathrm{g}$ in $100 \mu \mathrm{l}$ of DMEM. D) $25 \mu \mathrm{g}$ in $100 \mu \mathrm{l}$ of 5\% DMEM. E) $50 \mu \mathrm{g}$ IN $100 \mu \mathrm{l}$ of 5\% DMEM. F) $100 \mu \mathrm{g}$ IN $100 \mathrm{Ml}$ of 5\% DMEM.
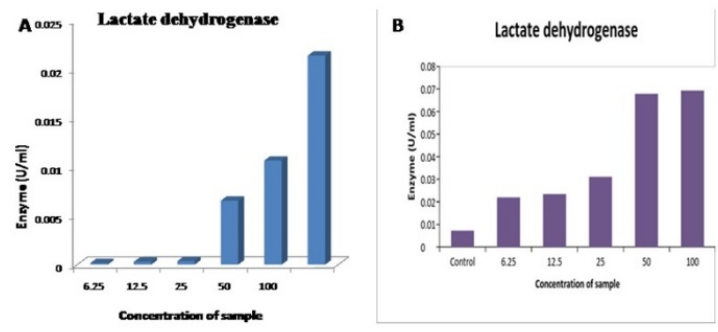

Figure 11: LDH leakage showing increase membrane permeability. Along $\mathrm{Y}$ axis enzyme Units/ $\mathrm{ml}$ and $\mathrm{X}$ axis concentration in $\mu \mathrm{g} / \mathrm{ml}$.

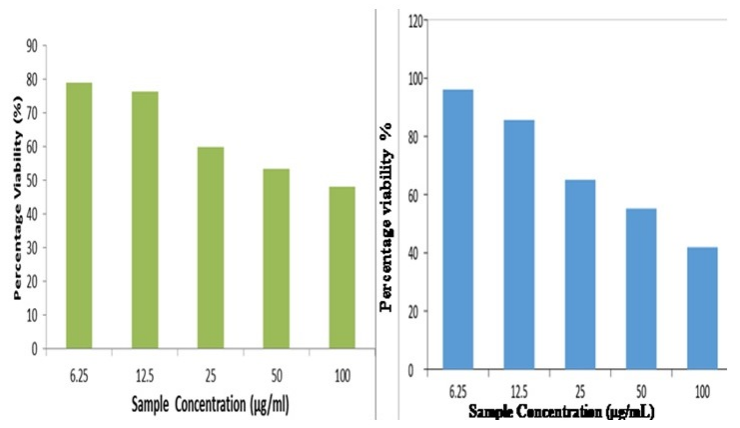

Fig. 12. Neutral red uptake assay showing decreased: Along $Y$ cxis enzyne units $/ \mathrm{ml}$ and $X$ coxis concentration in $\mu g / m l$.

Figure 12: Neutral red uptake assay showing decreased. Along Y axis enzyme units $/ \mathrm{ml}$ and $\mathrm{X}$ axis concentration in $\mu \mathrm{g} / \mathrm{ml}$.

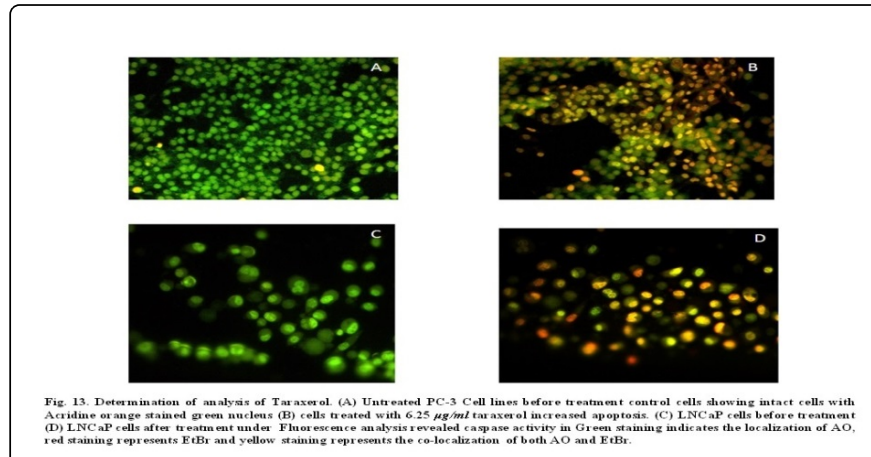

Figure 13: Determination of analysis of Taraxerol. A) Untreated PC-3 Cell lines before treatment control cells showing intact cells with acridine orange stained green nucleus. B) cells treated with $6.25 \mu \mathrm{g} / \mathrm{ml}$ taraxerol increased apoptosis. C) LNCaP cells before treatment. D) LNCaP cells after treatment under fluorescent analysys revealed caspase activity in Green staining indicates the localization of $\mathrm{AO}$ red staining represents $\mathrm{EtBr}$ and yellow staining represents the colocalization of both $\mathrm{AO}$ and $\mathrm{EtBr}$.

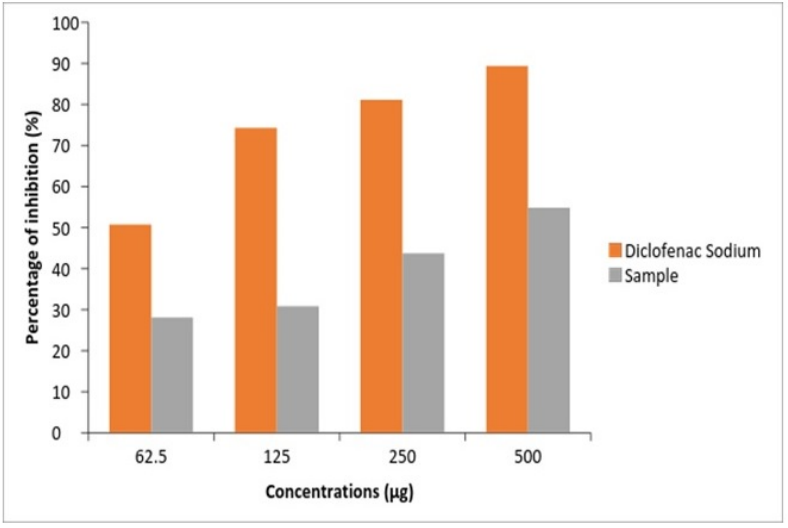

Fig. 14. Inhibition of Protein denaturation

Figure 14: Inhibition of protein denaturation. 


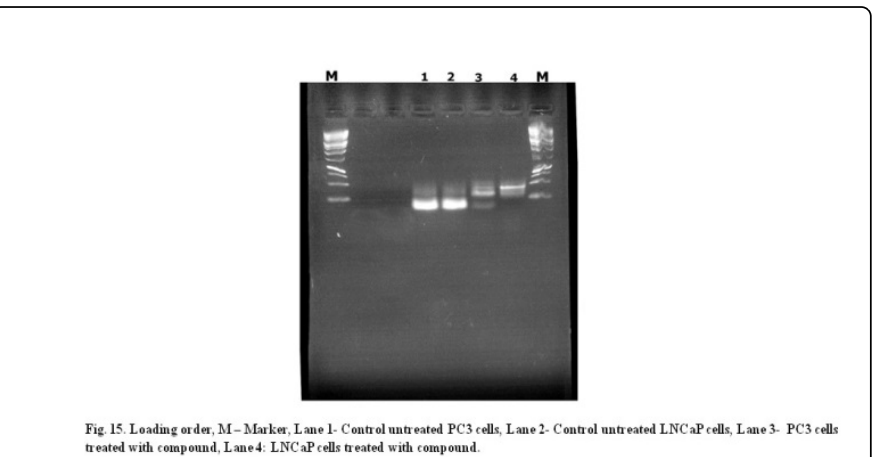

Figure 15: Loading order, M-Marker, Lane 1-Control untreated PC3 cells,Lane 2-Control untreated LNCaP cells, Lane 3- PC3 cells treated with compound, Lane 4-LNCaP cells treated with compound.
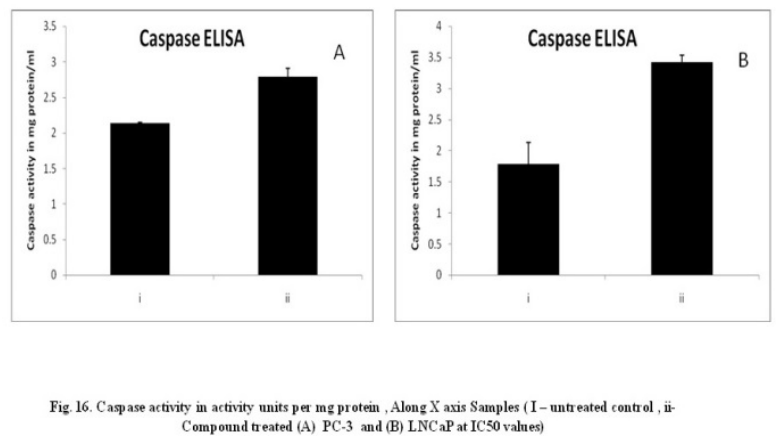

Figure 16: Caspase activity in activity units per mg protein. Along $\mathrm{X}$-axis samples (I-untreated control, ii- compound treated. A) PC-3. B) LNCaP at IC50 values).

\section{Conclusion}

The chemical components of $A$. reticulata $L$. is investigated which resulted in the separation of Taraxerol. The occurrence of Taraxerol is reported from $A$. reticulata $L$. bark species. So that it can be relayed that the sample Taraxerol is effective against the PC-3 and LNCaP cell lines loss of lysozymal function with treatment of compound was observed in a dose dependent manner suggesting anticancer activity. Results postulated that the Taraxerol is more cytotoxic and effective in inducing apoptosis.

\section{Acknowledgement}

The authors would like to express their gratitude to Dr. Divakar Goli, Principal and Mr. Premanath Reddy, Chairman and Mrs. Shalini Reddy, Secretary, Acharya Institute, Bangalore, India, for providing the necessary facilities and support to carry out the research work.

\section{References}

1. Lannang AM, Louh GN, Biloa BM, Komguem J, Mbazoa CD, et al. (2010) Cytotoxicity of natural compounds isolated from the seeds of Garciniaafzelii. Planta Med 76: 708-712.
2. Xu G, Kan LT, Zhou Y, Song JZ, Han QB, et al. (2010) Cytotoxic acylphloroglucinol derivatives from the twigs of Garciniacowa. J Nat Prod 73: $104-108$

3. Jacqueline B, Ivy C, Matthew M, Derek TP, Arianne MW, et al. (2014) Identification of genes regulating migration and invasion using a new model of metastatic prostate cancer. BMC Cancer 14: 404-438.

4. Brian T Helfand, William J Catalona (2014) The Epidemiology and Clinical Implications of Genetic Variation in Prostate Cancer. Urol Clin N Am 2: 277-297.

5. Yao X, Li G, Bai Q, Xu H, Lu C (2013) Taraxerol inhibits LPS-induced inflammatory responses through suppression of TAK1 and Akt activation. Int Immunopharmacol 15: 316-324.

6. Roopalatha UC, Vijay mala N (2013) Phytochemical analysis of successive reextracts of the leaves of moringaoleifera Lam. Int J Pharm Pharm Sci 5: 629-634.

7. Poongothai A, Sreena KP, Sreejith K, Uthiralingam M, Annapoorani S (2011) Preliminary phytochemicals screening of ficusracemosalinn. Bark. Int J Pharm Bio Sci 2: 431-436.

8. Santanu Sahaa, Subrahmanyam EVS, Chandrashekar K, Shashidhara C (2011) Isolation and characterization of triterpenoids and fatty acid ester of triterpenoid from leaves of Bauhinia variegate. Der PharmaChemica 4: 28-37.

9. Suvarchala Reddy NVL, Kusuma Priyanka AY, Raghavendra NM (2012) Isolation and characterization of triterpenoids from bark of Syzygiumalternifolium (Wight) Walp. Ann Phytomed 2: 45-51.

10. Tamimi R, Sepehri H, Delphi L (2016) Experimental Induction of Apoptosis by Salvia sahendica Extract Alone and in Combination with Doxorubicin in Human Prostate Cancer Cells, LNCaP. Int J Pharmacogn Phytochem Res 8: 272-283.

11. Deep G (2016) Graviola inhibits hypoxia-induced NADPH oxidase activity in prostate cancer cells reducing their proliferation and clonogenicity. Sci Rep 23: 231-35.

12. Zhang JH, YU J, Li WX, Cheng CP (1998) Evaluation of Mn2+ stimulated and $\mathrm{Zn} 2+$ inhibited apoptosis in rat corpus luteal cells by flow cytometry and fluorochromes staining. Chin J Physiol 41: 121-126.

13. Anna L, Manjola B, Cristina C, Maria Novella R, Francesco P (2013) Effectiveness of the Histone Deacetylase Inhibitor (S)-2 against LNCaP and PC3 Human Prostate Cancer Cells. PLOS ONE 8: 3-5.

14. Daj MM, Niu X, Zhao Z, Brown JM, Russell PJ (2003) Characterization of expression of matrix metalloproteinases and tissue inhibitors of metalloproteinases in prostate cancer cell lines. Prostate Cancer and Prostatic Dis 6: 15-26.

15. Borenfreund, E, Borrero O (1984) In vitro cytotoxicity assays: Potential alternatives to the Draize ocular irritancy test. Cell Biol Toxicol 1: 55-65.

16. Shukranul M, Ikram M Said (2012) Chemical Constituents of Garciniaprainiana, Sains. Malaysiana. 41: 585-590.

17. Tan B, Shi HL, Ji G, Xie JQ (2016) Effects of Taraxerol and Taraxerol acetate on cell cycle and apoptosis of human gastric epithelial cell line AGS. Zhong Xi Yi Jie He Xue Bao 168: 638-642.

18. Mitja M, Irena V, Breda S (2009) Separation and identification of some common isomeric plant triterpenoids by thin-layer chromatography and high-performance liquid chromatography. J Chromatogr A 1216: 66626670.

19. Susana S Ramos, Luís R, Mafalda C, Adriano T, Paulo A (2007) Mass spectrometric analysis of epimeric $3 \alpha / 3 \beta$ functionalized steroids. ARKIVOC 6: 163-171.

20. Thang TD, Kuo PC, Huang GJ, Hung NH, Huang BS (2013) Chemical constituents from the leaves of Annona reticulata and their inhibitory effects on NO production. Molecules 18: 4477-4486.

21. Zhang JH, YU J, Li WX, Cheng CP (1998) Evaluation of Mn2+ stimulated and $\mathrm{Zn} 2+$ inhibited apoptosis in rat corpus luteal cells by flow cytometry and fluorochromes staining. Chin J Physiol 41: 121-126.

22. Anna L, Manjola B, Cristina C, Maria NR, Francesco P (2013) Effectiveness of the Histone Deacetylase Inhibitor (S)-2 against LNCaP and PC3 Human Prostate Cancer Cells. PLOS ONE 8: 3-5. 